\title{
A comparison between two different biomaterials for treatment of tracheal defect in dogs
}

\author{
O.H. Al-Hyani* and A. M. Al-Hasan \\ Department of Surgery and Theriogenology, College of Veterinary Medicine, University of Mosul, Mosul, Iraq \\ *Email: osamahazim854@yahoo.com
}

(Received November 5, 2018; Accepted January 7, 2019)

\begin{abstract}
This study was designed to evaluate the healing process of tracheal cartilage defect after implantation of two different biomaterials in dogs. Eighteen adult dogs from both sexes were used. They were divided into 2 equal groups. A window shape defect of about $3 \mathrm{~cm} \times 2 \mathrm{~cm}$ was induced in the cervical part of three adjacent tracheal rings with their annular ligaments. In group one, the defect was closed with a small strip of ear cartilage (auto graft) from the same animal, while in the second group, calf's pericardium scaffold (xeno graft) was used to close the defect. All the animals were clinically monitored postoperatively, while gross pathological changes and biopsy collections for all animals was performed at 15, 30, 60 postoperative days. No postoperative clinical complications were recorded and all were looking healthy and resuming food and water intake normally. The gross pathological results revealed rapid occlusion to the trachea especially in first group and animals survived without any respiratory complications. The histological features in both groups were represented by newly granulation tissue formation and hyaline cartilage regeneration. The new hyaline cartilage cells formation was showed faster in group 1 rather than group 2. In conclusion, both grafts can be used for closing a tracheal defect in dogs with the priority of ear cartilage implantation.
\end{abstract}

Keywords: tracheal defect healing, ear cartilage, bovine pericardium Available online at http://www.vetmedmosul.com

$$
\begin{aligned}
& \text { مقارنة بين مادتين بايولوجيتين مختلفتين لعلاج الأذى في القصبة الهوائية للكلاب } \\
& \text { أسامة حازم الحياني و عبد الحليم مولود الحسن } \\
& \text { فرع الجراحة و علم تناسل الحيوان، كلية الطب البيطري، جامعة الموصل، الموصل، العراق }
\end{aligned}
$$

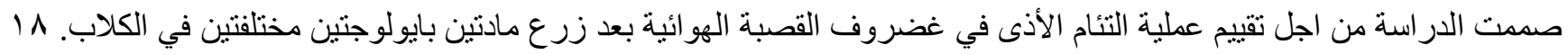

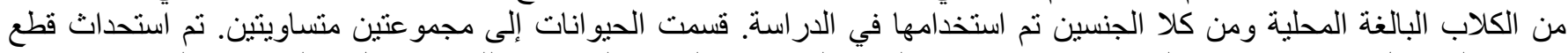

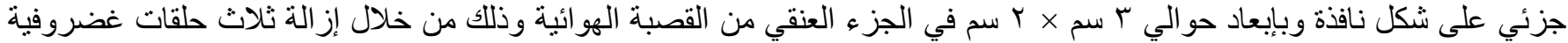

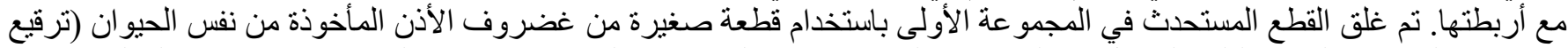

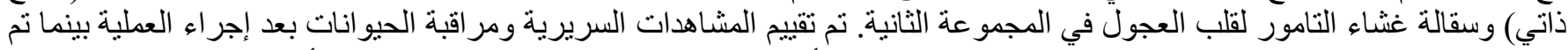

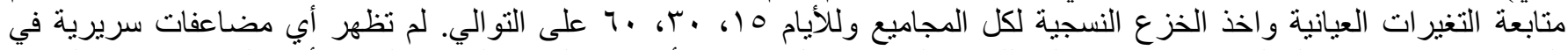

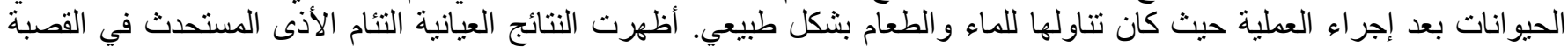

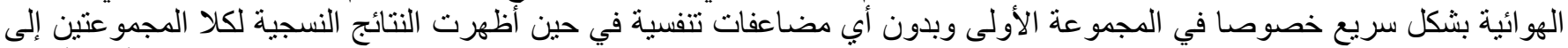

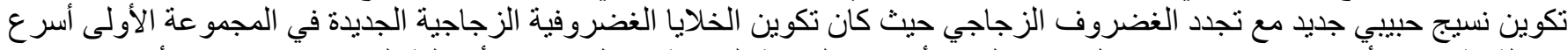

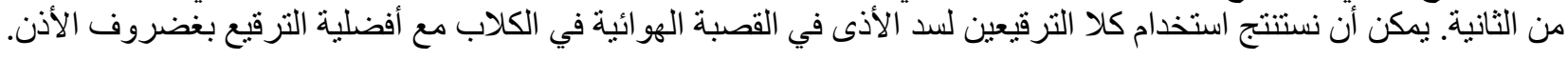




\section{Introduction}

Trachea is a flexible, non-collapsed, tubular organ extended from the larynx to its bifurcations. It consists of 35-45 semicircular or C- shaped hyaline cartilages which are linked to each by the annular ligaments which are fibro elastic in nature that make the trachea adaptable with cervical movement (1-3). Injury of trachea may be high risky, so surgical intervention is considered as the treatment of choice (4-6). Minor wounds of trachea can be treated by suturing but if it is associated with necrosis or infection, it should be debrided with local and systemic antibiotic therapy application (7). The restoration of large tracheal defects considered a challenging problem in tracheal surgery (8-10). Prosthetic tracheal repair is difficult and associated with complications as long as the prosthesis is not incorporated by the host (11). Factors that reducing the successfulness of tracheal surgery and retarded healing are poor blood supply, rigidity of the cartilaginous rings and difficulty in apposition of wound edges (12). Excision of more tracheal segments usually needs the application of artificial materials or autogenous tissues for repairing (13). Transplantation of biological scaffolds has been used by surgeons with a variable result (14-16). Reconstruction of cartilage defects by using cartilage graft considered a regular challenge for surgeons. To repair a cartilage defect, autologous cartilage is preferable choice to prevent the risk of diseases transmission and to avoid immunologic reactions. Rib or pinna cartilage is commonly used (17-19). In experimental study on beagle dogs a tracheal reconstruction with the use of external ear canal autografts was concluded a moderate success. There were no serious complications or loss of a physiologic airway (20). The pericardium has been widely used as a biomaterial tissue or biopsy theses applied, for construction of a variety of tissues such as vascular grafts, patches for abdominal or vaginal wall repair and heart valves (21). Pericardium also reported to be also used to correction of congenital tracheal and esophageal stenosis $(22,23)$. Additionally, pericardium in combination with polytetrafluorethylene have been used for sealing of cut surface in lobectomy of the lung (24), as well as pericardial flaps combined with marlex mesh have been also used for tracheal repair (25). The aim of this research is to study the efficiency of ear cartilage and bovine pericardium scaffold as a biomaterial implants for repairing tracheal defect in dogs.

\section{Materials and methods}

Eighteen local breed adult dogs from both sexes were used, which were divided into 2 equal groups. All operations were conducted under general anesthesia by I.M. injection a mixture of ketamine HCL at $15 \mathrm{mg} / \mathrm{kg}$ and xylazine $2 \%$ at $5 \mathrm{mg} / \mathrm{kg} \mathrm{B}$.W. In both groups intubation of the trachea was carried. Incision of about $10 \mathrm{~cm}$ was made though skin and subcutaneous tissue between the middle and last $3^{\text {rd }}$ of the ventral aspect of the neck, the sternohayoidous muscles were bluntly dissected to locate the trachea (Figure 1). A window like defect about $(3 \mathrm{~cm} \mathrm{x}$ $2 \mathrm{~cm}$ ) was induced in the trachea (Figure 2).

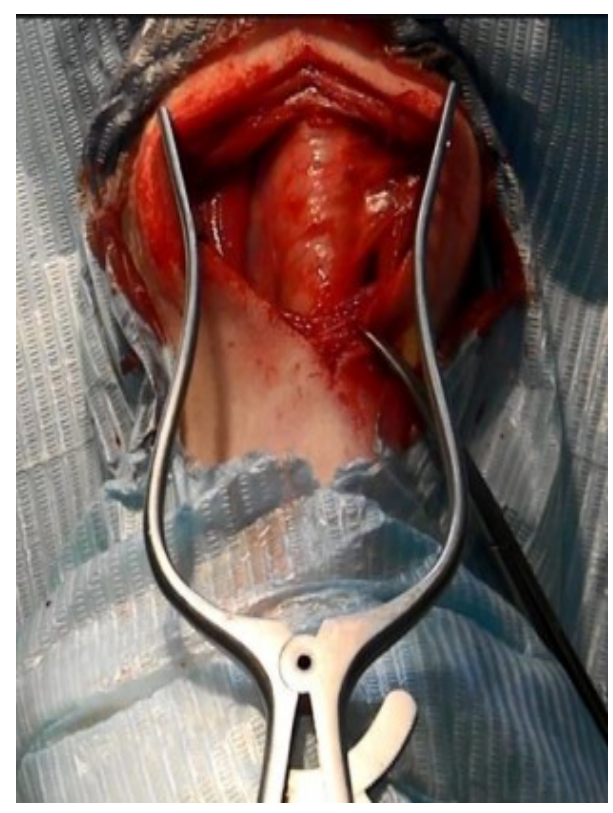

Figure 1: Showing exposure of trachea.

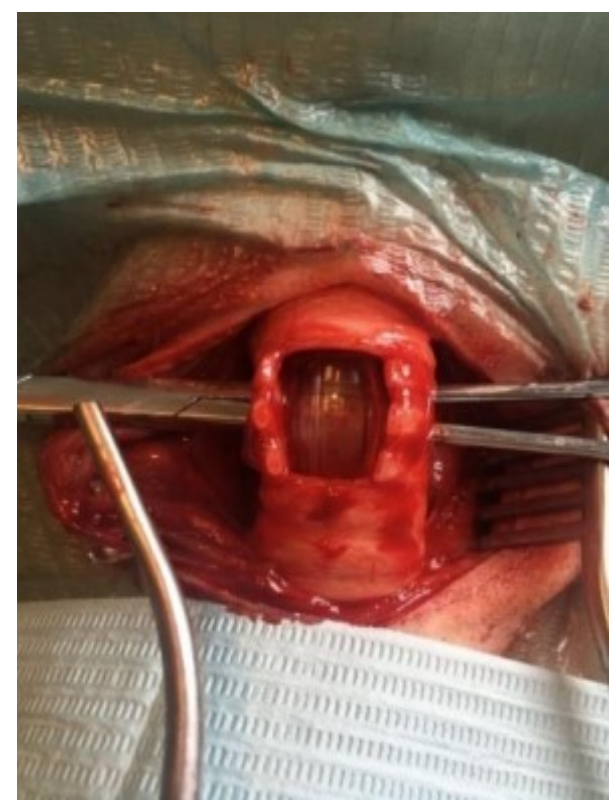

Figure 2: Showing tracheal defect. 
In group one, the defect was closed by tacking apiece or strip of cartilage that sacrificed from the ear of the animal (autologous graft). Ear flap cartilage has been extracted by careful dissection of the firmly contact skin, and directly kept in normal saline that containing antibiotic (penicillinstreptomycin) until the completion of suturing and dressing of the sacrificed ear flap (Figure 3). Then the sacrificed cartilage was implanted on the tracheal defect and fixed with few simple interrupted stitches using 3/0 nylon suture (Figure 4).The endotracheal tube was removed from the trachea, then muscles and skin was closed.

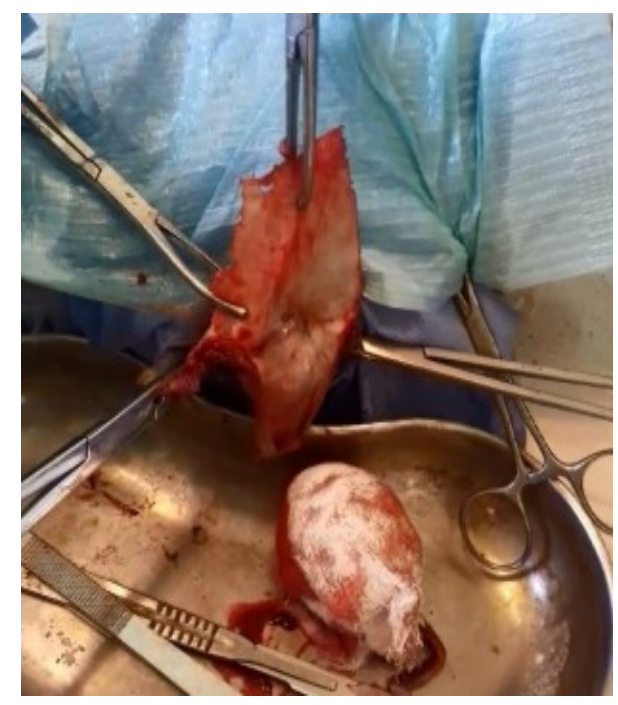

Figure 3: Showing sacrificed ear cartilage.

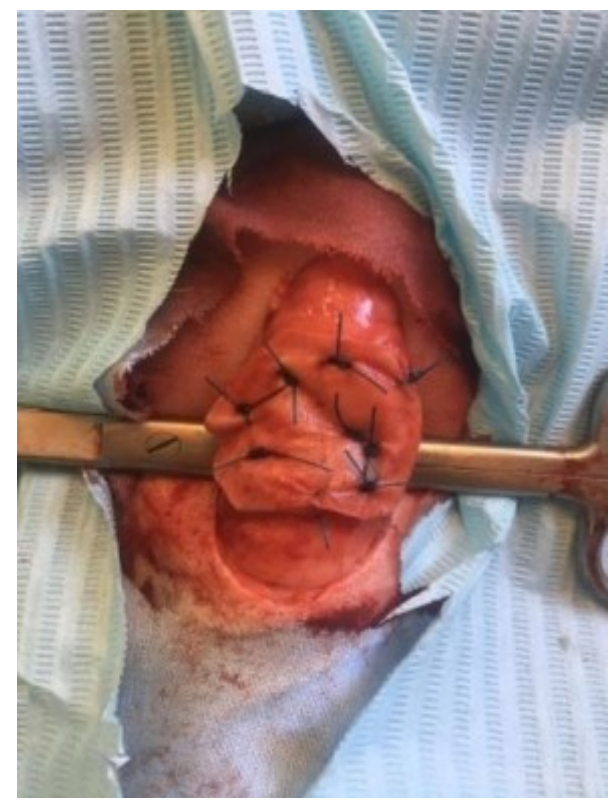

Figure 4: Showing suture ear cartilage with trachea.
In group two, the tracheal defect was closed by a pericardium scaffold (xenograft) which was obtained from newly slaughtered calves. The collected pericardium was preserved in sterile normal saline with antibiotic (same as used for ear cartilage) until it prepares the trachea for implantation. A suitable piece from the scaffold was trimmed from the pericardium (Figure 5), and was applied on the defect with its smooth surface facing the lumen of the trachea and then fixed to the defect by the same manner used for fixation of ear cartilage (Figure 6). Finally, the surgical wound was closed.

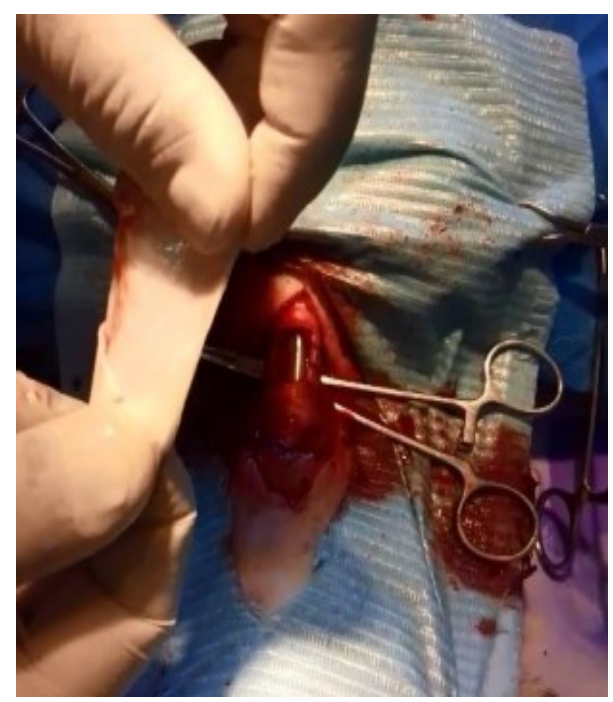

Figure 5: Showing piece of bovine pericardium.

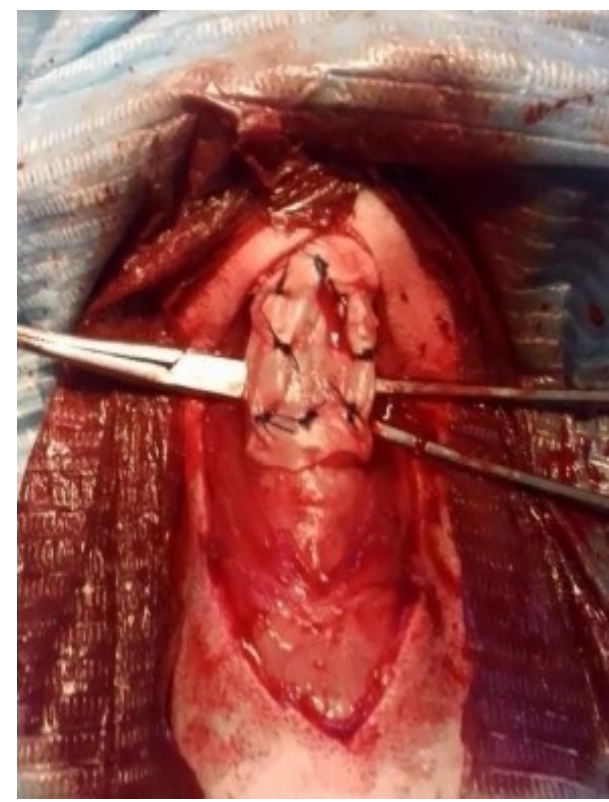

Figure 6: Showing suture bovine pericardium with trachea. 
The experimental animals were received antibiotics injection (penicillin streptomycin in a dose 10,000 I.U. $/ \mathrm{kg}$ B.W. penicillin and $10 \mathrm{mg} / \mathrm{kg} \mathrm{B.W}$. streptomycin) for 3 days by I.M. route. Assessment and evaluation of grafting results was depended on the clinical observations and gross pathological changes and biopsy collection for histopathological interpretation were performed in both groups at 15,30,60 postoperative day on 3 animals from each group in the suggested times.

The biopsies were fixed in $10 \%$ buffered formalin solution, then processed and stained with routine Harris hematoxylin and eosin (HE) as well as Masson' s trichrome stain (MT) as a special stain.

\section{Results}

In all experimental animals, there was slight swelling at the surgical site which was gradually subsided within a few days after surgical operation. No signs of respiratory obstruction or respiratory distress were noticed. The animals were resuming food and water intake normally. The only problem in group one was the asymmetry appearance between the two ears resulted from scarification of one ear flap causing cosmetic disturbance of the animal.

\section{Gross pathological findings}

In group one, adhesion was developed between the implanted cartilage and the surrounding tissues on 15 postoperative days then it was gradually diminished at 30 and 60 postoperative day. The gross inspection after 60 days showed a perfect fusion between the implanted cartilage and the outer surface of the trachea which indicates a complete sealing of the induced defect (Figure 7), while the mucosal surface of the implanted cartilage revealed presence of a depression between the trachea and the implanted cartilage (Figure 8), this depression relatively disappeared after 30 day, but still exists (Figure 9), and completely disappeared after 60 days (Figure 10). No tracheal stenosis or any excessive tissue growth in the mucosal surface at the site of implantation was recorded.

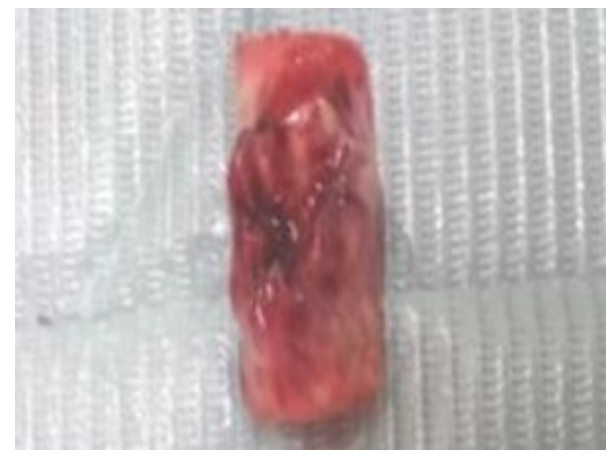

Figure 7: Show site of graft on 60 postoperative day in G1.

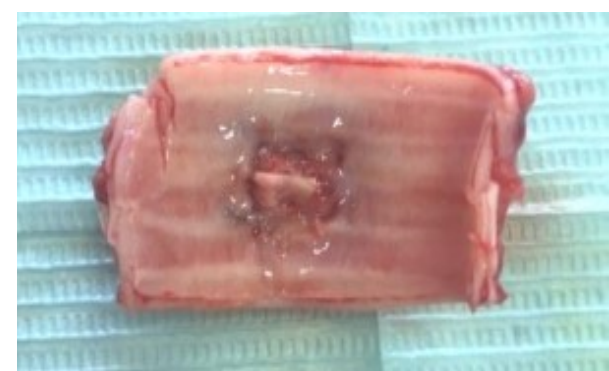

Figure 8: Show tracheal defect on 15 postoperative day in G1.

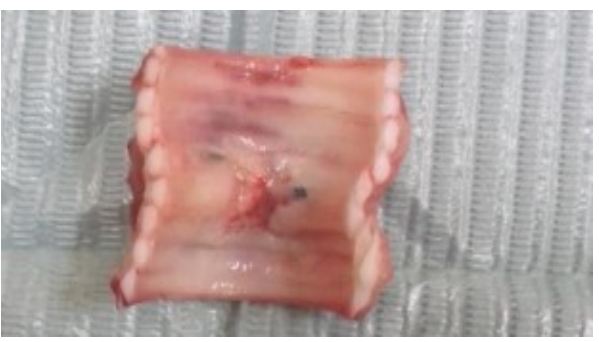

Figure 9: Show tracheal defect on 30 postoperative day in G1.

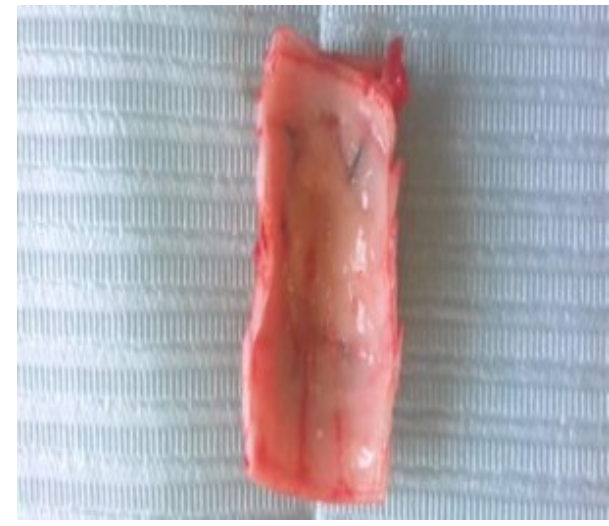

Figure 10: Show tracheal defect on 60 postoperative day in G1.

In second group, adhesions were seen between the pericardium scaffold and surrounding tissue on 15 postoperative day which were diminished gradually after 30 and 60 postoperative days respectively. The gross examination shows a good interwoven between the implanted pericardium scaffold and the outer surface of the trachea at the site of implantation (Figure11). Like in group one, a depression was noticed on the mucosal surface of the trachea in the site of implantation on 15 post-operative day (Figure 12), then slightly reduced after 30 days (Figure 13), and completely vanished on 60 postoperative day (Figure 
14). Also, no stenosis or any abnormal or tissue over growth was noticed in the tracheal canal.

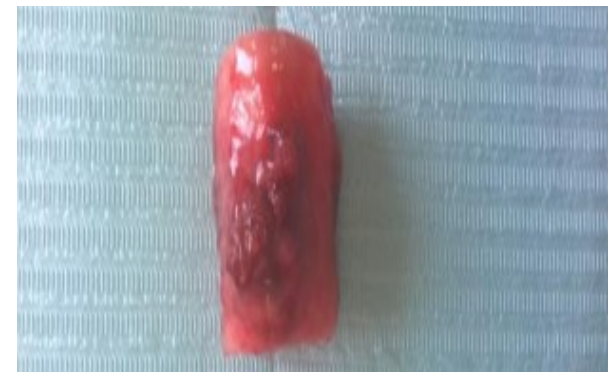

Figure 11: Show site of graft on 60 postoperative day in G2.

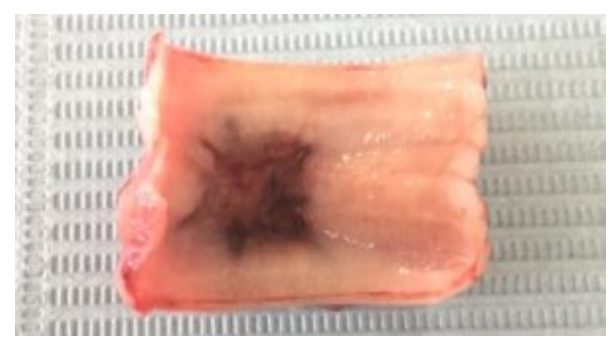

Figure 12: Show tracheal defect on 15 postoperative day in G2.

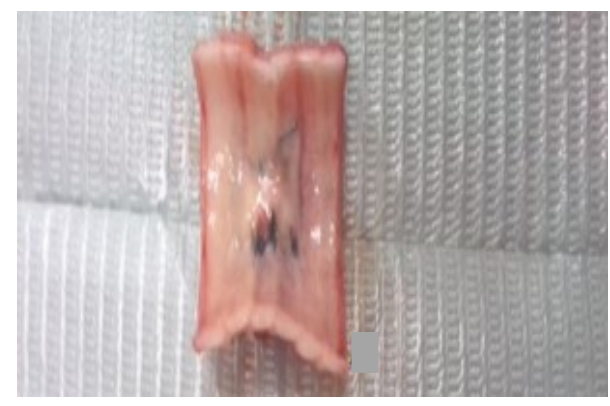

Figure 13: Show tracheal defect on 30 postoperative day in $\mathrm{G} 2$.

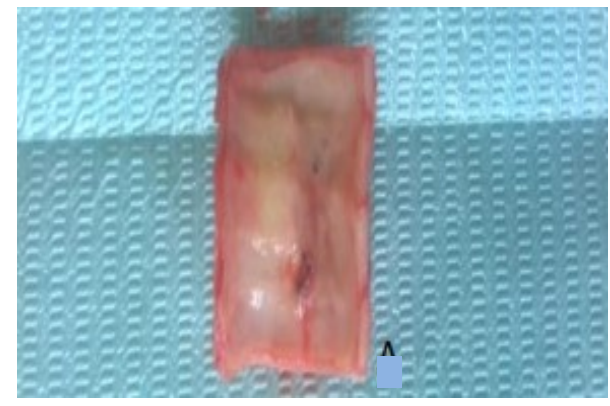

Figure 14: Show tracheal defect on 60 postoperative day in $\mathrm{G} 2$.

\section{Histopathological findings}

In group one, after $15^{\text {th }}$ postoperative day, the histological features were reveled disappearance of ciliary surface of epithelial layer of trachea, degeneration and necrosis of epithelial cells was observed (Figure 15). Thickening of mucosal layer as a result of infiltration of lymphocyte and fibrosis (Figure 16). Also, there were cartilage necrosis with infiltration of inflammatory cells beneath it (Figure 17). There were inflammatory cells located in the outer layer of trachea and new granulation tissue formation. Around the implantation of ear cartilage, area of new cartilage formation was showed also (Figure 18). Staining with Masson's trichrome was reveled pronounced proliferation and maturation of collagen fibers. At 30 postoperative day, the epithelial ciliary surface was disappeared. Area of necrosis of chondrocytes of tracheal cartilage was observed. Additionally, there was connective tissue with new angiogenesis surrounding the inserted cartilage (Figure 19). Also, by Masson's trichrome there was sever maturation of collagen fibers (Figure 20). At 60 postoperative day, the sub mucosal layer of hyaline cartilage was disappeared with disappearance of epithelial lining of mucosal layer. Good fusion of ear cartilage by mature connective tissue which composed of fibroblast, collagen fibers, and newly blood vessels and no inflammatory reaction was observed (Figure 21). Also, there was new cartilage formation (Figure 22).

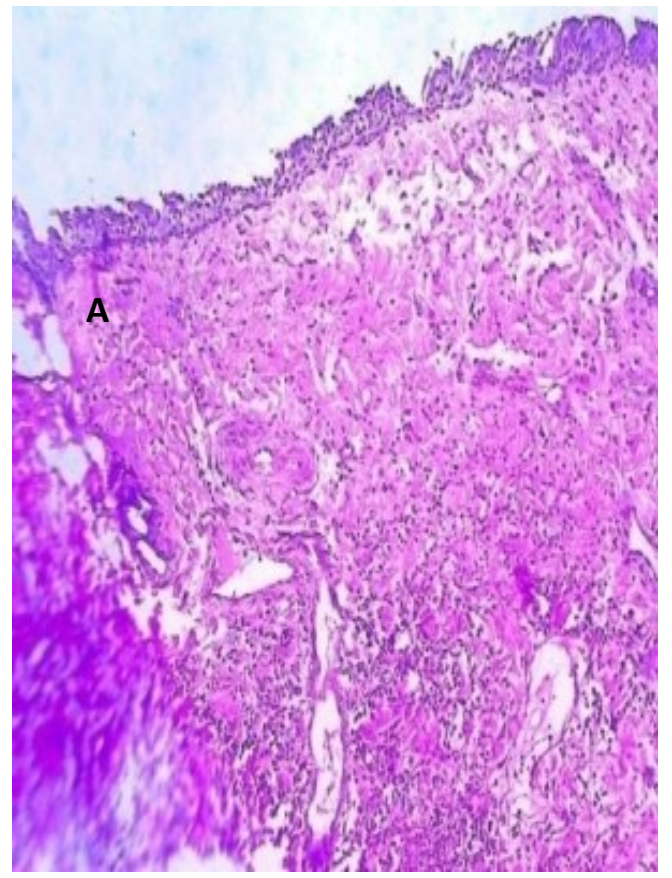

Figure 15: Tracheal defect on 15 postoperative day in G1 showing degeneration and necrosis of epithelial cells of trachea (A). HE, x40. 


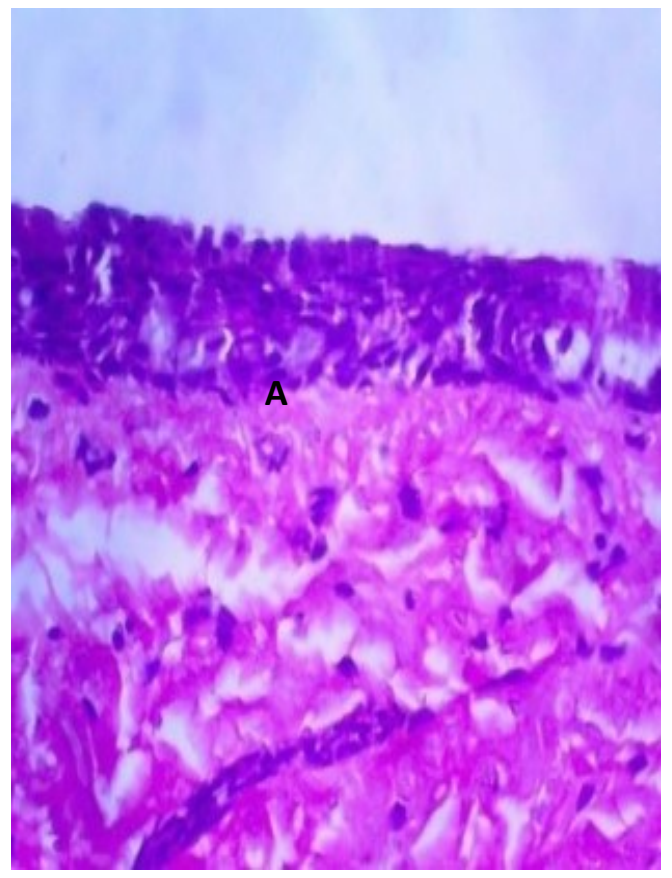

Figure 16: Tracheal defect on 15 postoperative day in G1 showing thickening in mucosa due to infiltration of lymphocyte and fibrosis (A). HE, x10.

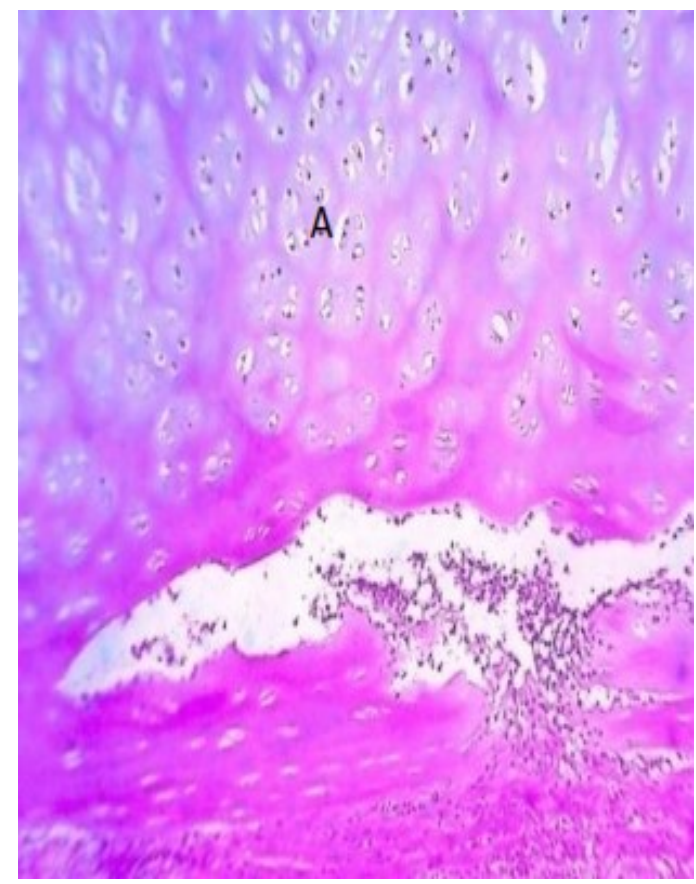

Figure 17: Tracheal defect on 15 postoperative day in G1 showing cartilage tissue necrosis (A). HE, x10.

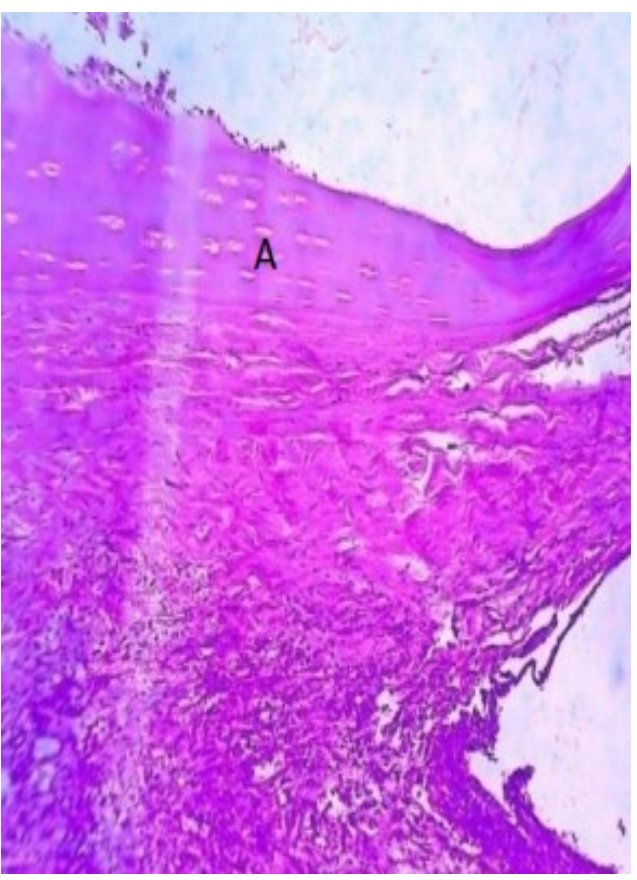

Figure 18: Tracheal defect on 15 postoperative day in G1 showing new cartilage formation (A). HE, x10.

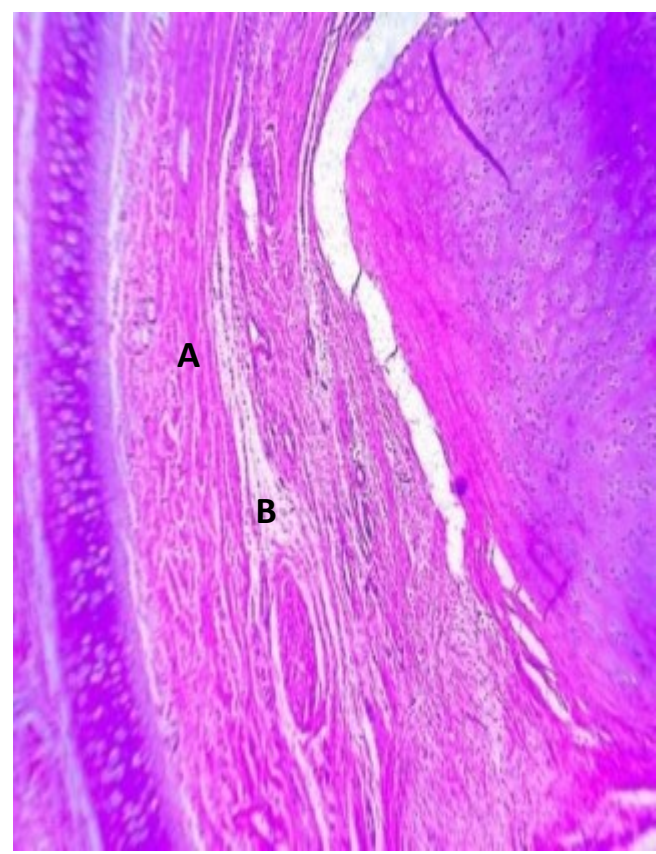

Figure 19: Tracheal defect on 30 postoperative day in G1 showing insertion of ear cartilage with trachea by connective tissue (A) with newly vessels (angiogenesis) (B). HE, x10. 


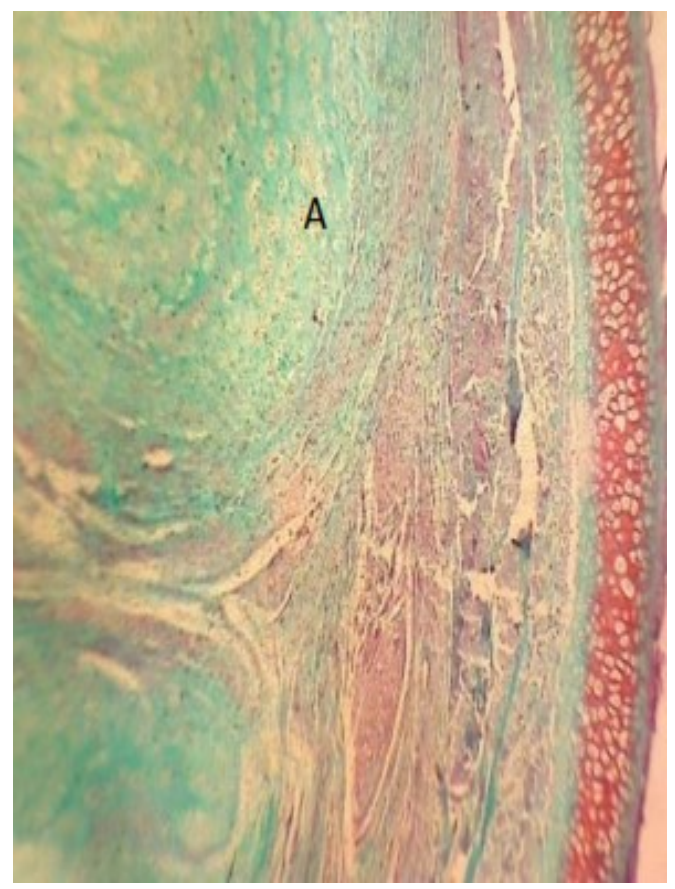

Figure 20: Tracheal defect on 30 postoperative day in G1 showing sever maturation of collagen fibers (A). MT, $x 4$.

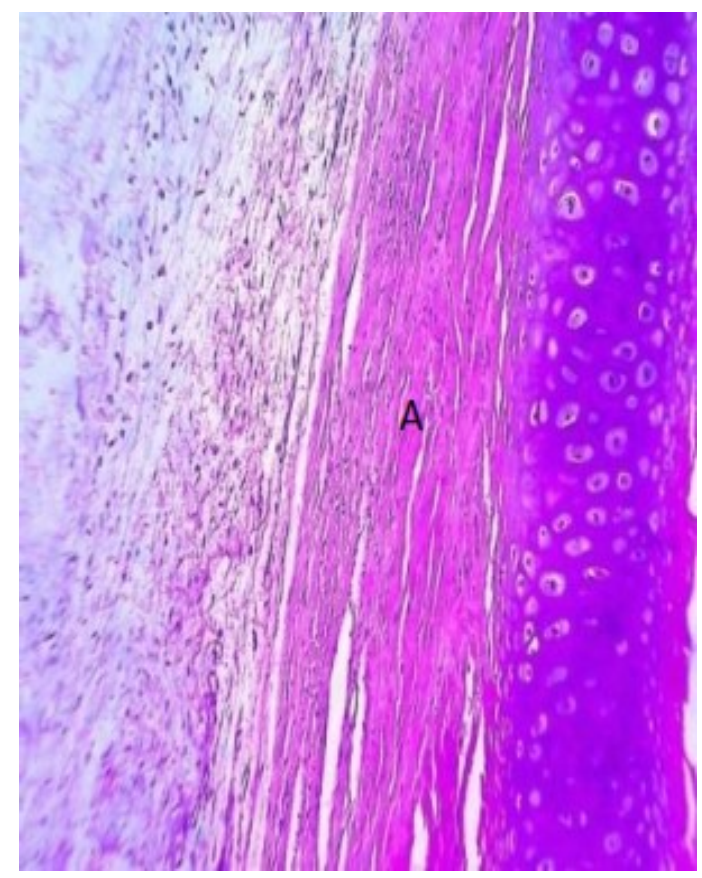

Figure 21: Tracheal defect on 60 postoperative day in G1 showing insertion ear cartilage with trachea by collagen fibers and fibroblast with new vessels (A). HE, X10.

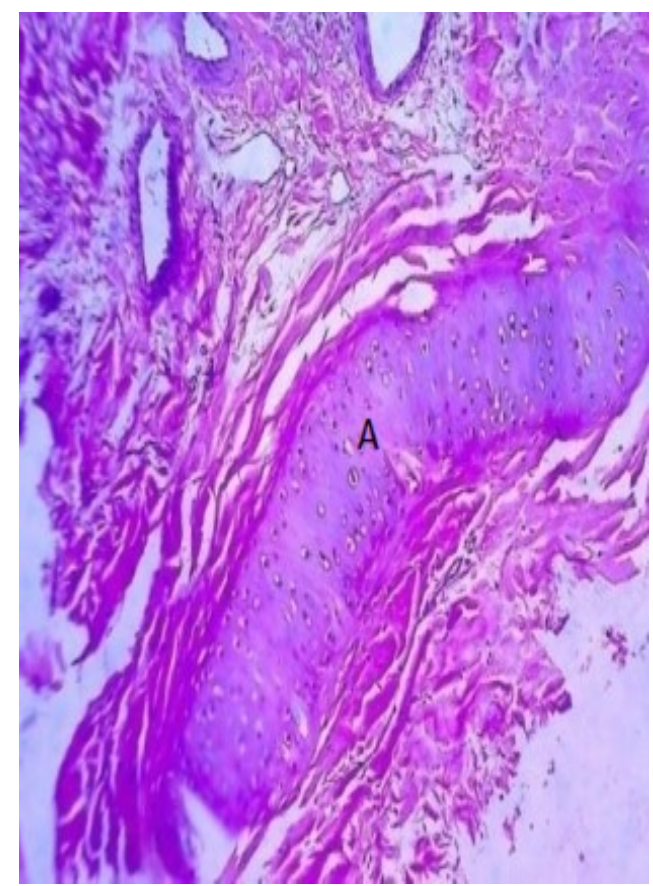

Figure 22: Tracheal defect on 60 postoperative day in G1 showing new cartilage tissue formation (A). HE, X10.

In second group at 15 postoperative days, the histological features were reveled new granulation tissue formation (Figure 23) with high infiltration of inflammatory cells (Figure 24). Some sections were showed disappearance of ciliary surface of epithelial layer of trachea, degeneration and necrosis of epithelial cells was observed. There was highly vascularization with a moderate inflammatory response within the connective tissue (Figure 25). Sever changes of new capillaries was observed. There was strong impact or connection of pericardium with trachea was showed. By Masson's trichrome there was sever proliferation and maturation of collagen fibers. At 30 postoperative day, there were presence of dense connective tissue that connect pericardium to under lying tissue of trachea (Figure 26), new cartilage formation was also showed. Collagen organization and fibrils of collagen was observed (Figure 27). Also, chronic inflammatory process was present which characterized by infiltration of mononuclear cells around and within connective tissue. Area of necrosis of chondrocytes of tracheal cartilage was observed. By Masson's trichrome there was increasing in severity of maturation of collagen fibers (Figure 28). At 60 postoperative day, the chronic granulomatous process was developed and characterized by infiltration of mono nuclear cells (lymphocytes, macrophages and plasma cells (Figure 29). Also, there was a mature connective tissue with observation of a new cartilage growth (Figure 30). 


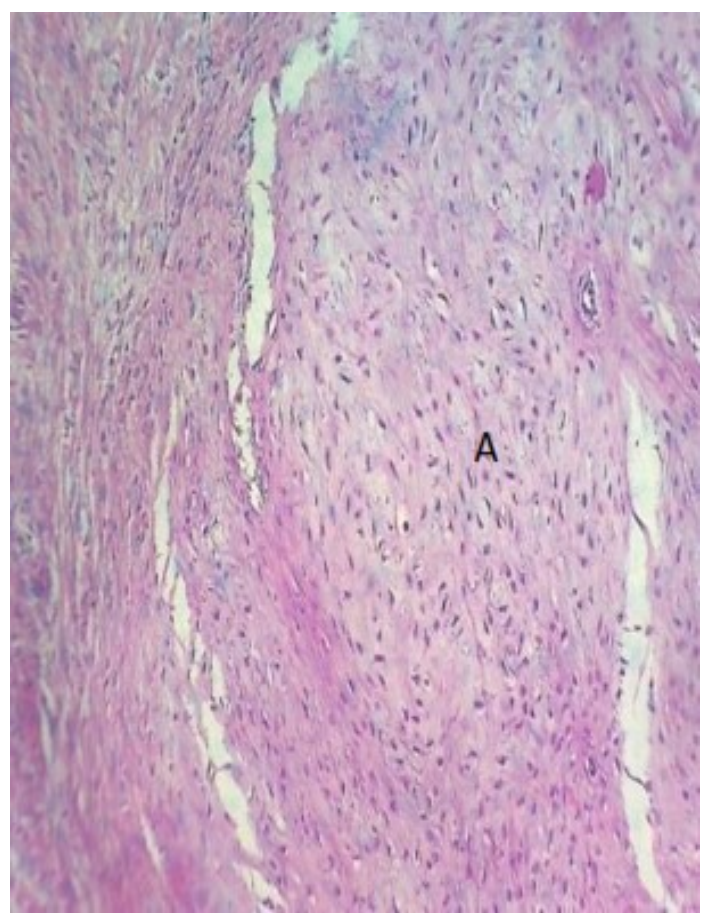

Figure 23: Tracheal defect on 15 postoperative day in G2 showing new granulation tissue formation(A). HE, X10.

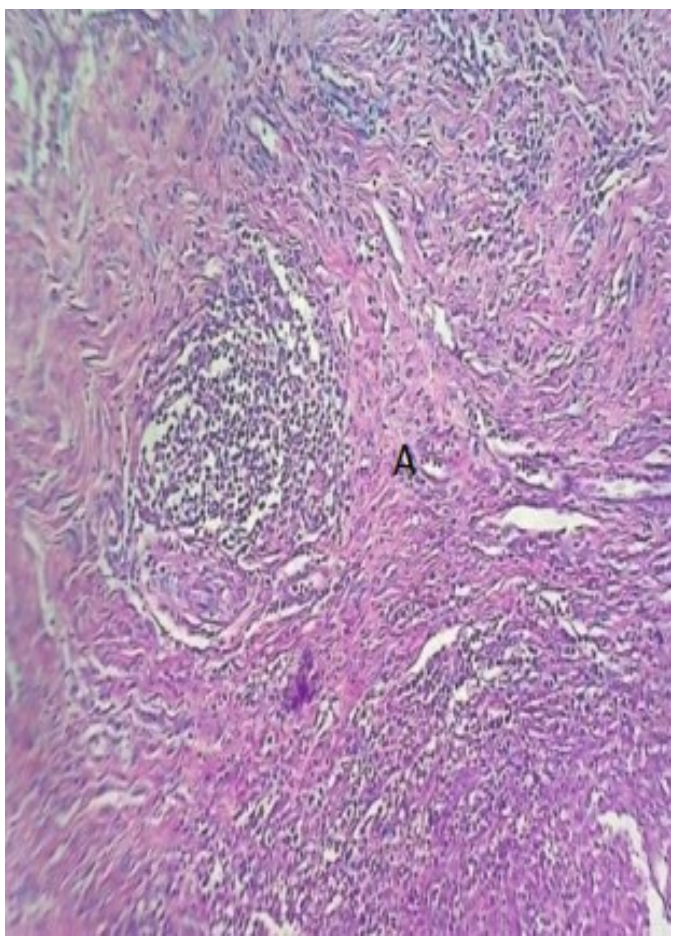

Figure 24: Tracheal defect on 15 postoperative day in G2 showing infiltration of inflammatory cells (granulomatous reaction) (A). HE, X10.

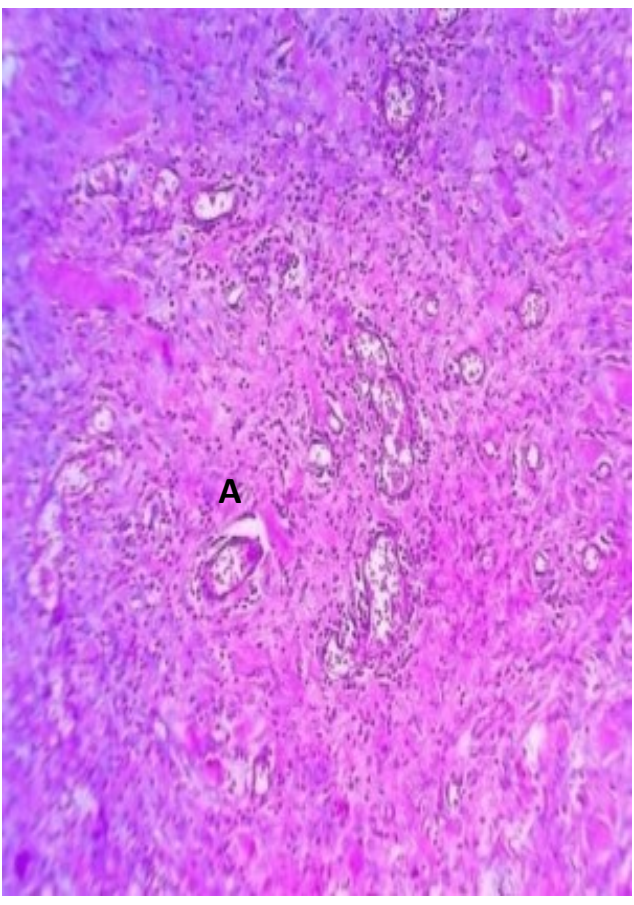

Figure 25: Tracheal defect on 15 postoperative day in G2 showing highly vascularization with moderate inflammatory response (A). HE, X10.

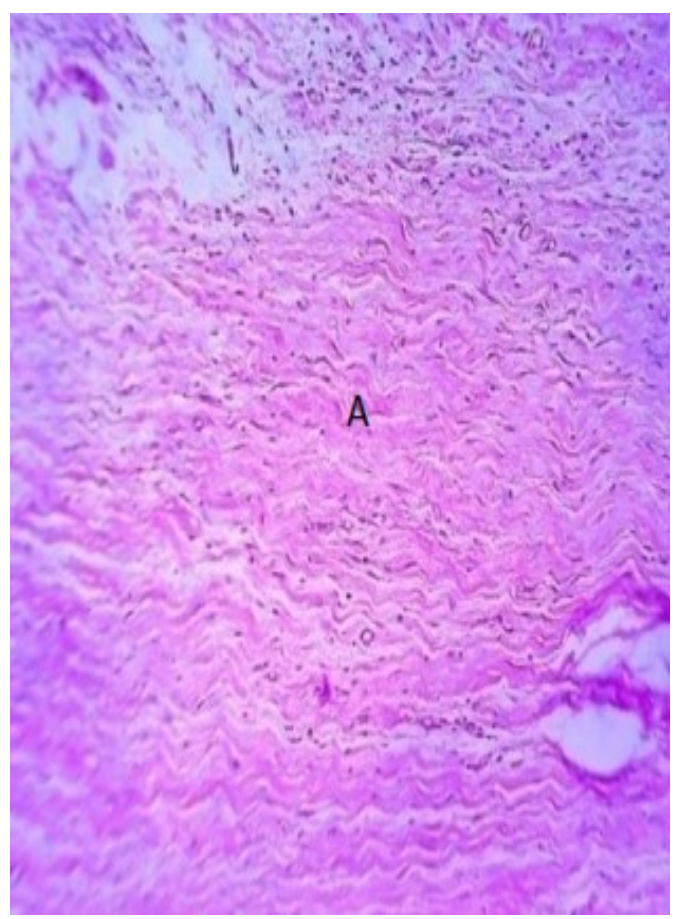

Figure 26: Tracheal defect on 30 postoperative day in G2 with showing a dense connective tissue (A). HE, X10. 


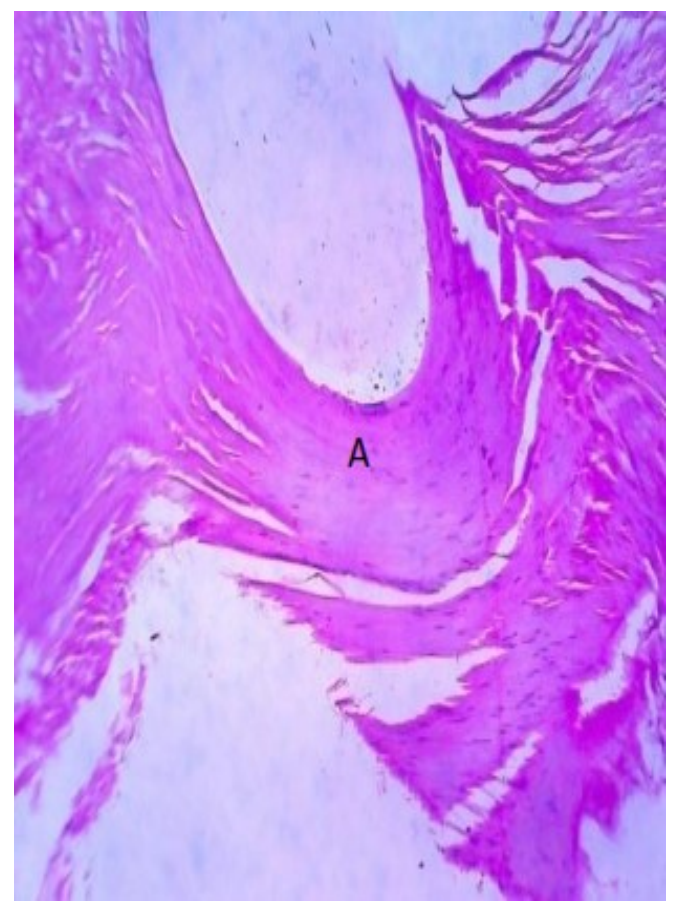

Figure 27: Tracheal defect on 30 postoperative day in G2 with showing Collagen organization and fibrils of collagen(A). HE, X10.

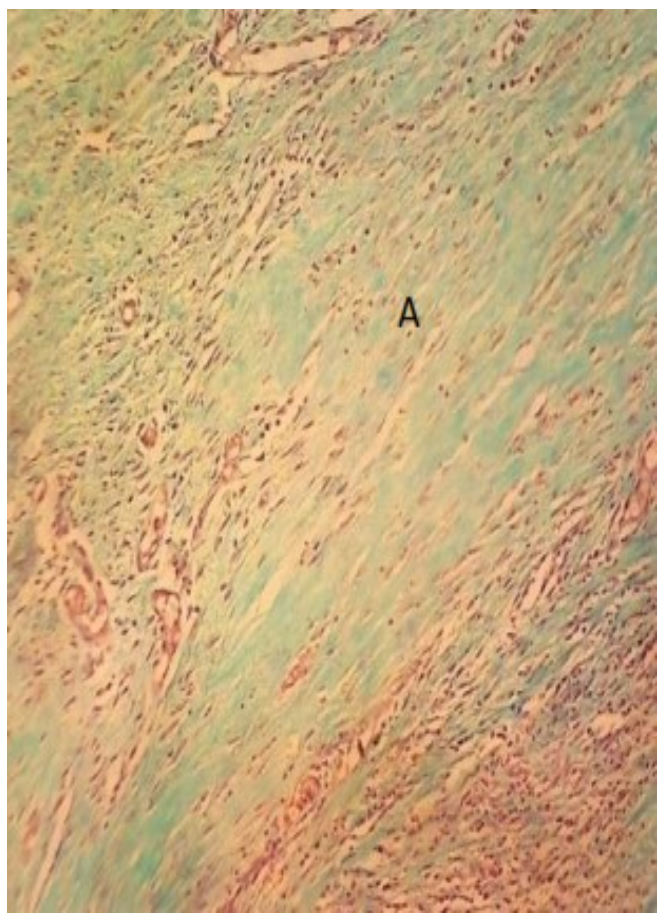

Figure 28: Tracheal defect on 30 postoperative day in G2 showing sever maturation of collagen fibers (A). MT, X10.

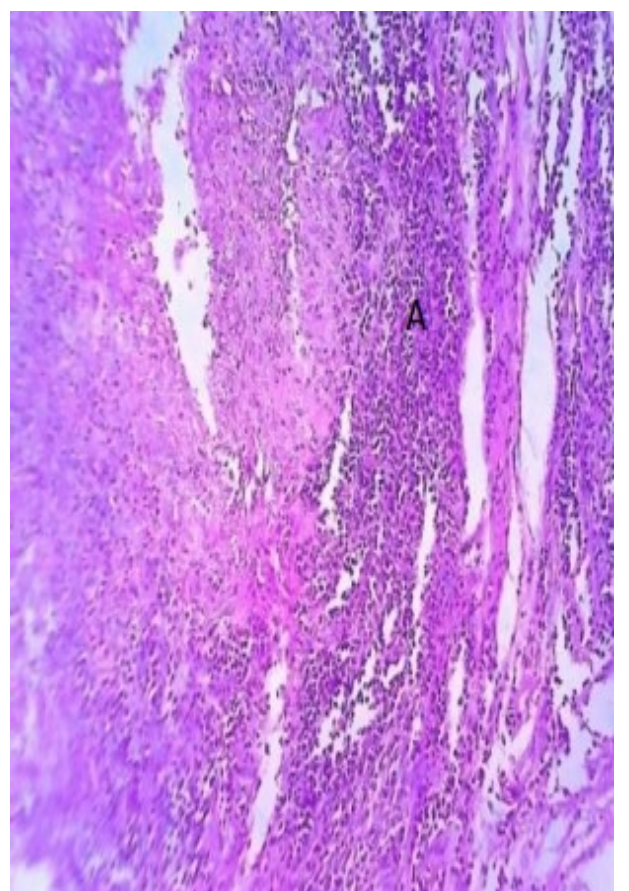

Figure 29: Tracheal defect on 60 postoperative day in G2 showing infiltration of mononuclear inflammatory cells (lymphocyte, macrophage and plasma cells) (A). HE, X10.

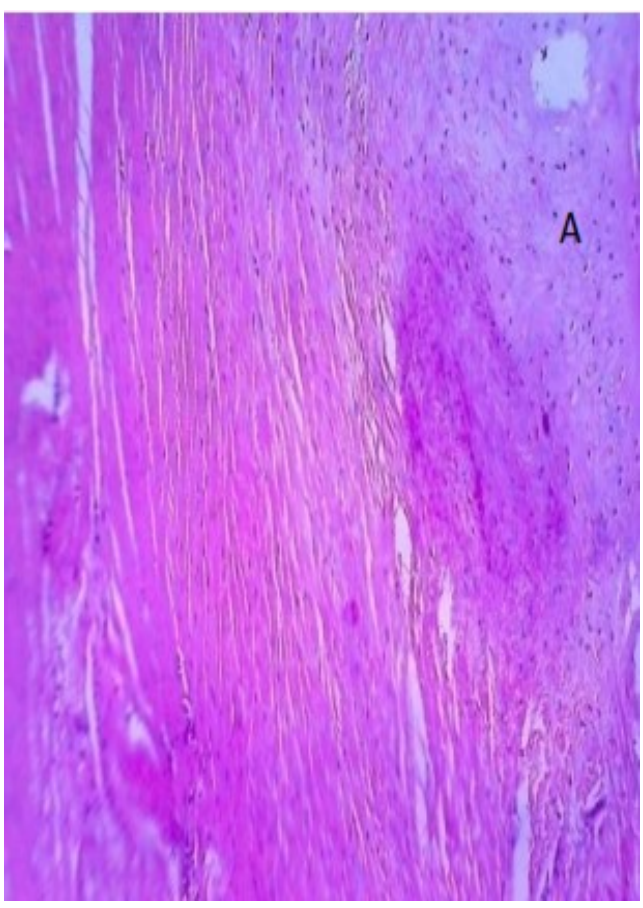

Figure 30: Tracheal defect on 60 postoperative day in G2 showing new cartilage formation (A). HE, X10. 


\section{Discussion}

In group one the tracheal defect was completely sealed without interference with the intra-tracheal air flow by overgrowth of granulation tissue. This feature: indicated the success of repairing the tracheal defect with ear cartilage without any complications. This finding resemble to Athar et al. (26) who suggested that growth factors such as IGF-I might play a role in cartilage wound healing and repair during trauma to articular cartilage although the capacity of cartilage wound healing is generally considered to be poor. In group two the use of pericardium to close the tracheal defects also showed up a good result that might be attributed to the authors conclusion (27-29) that bovine pericardium (BP) rich in collagen containing commonly type-I, as well as glycosaminoglycans (GAGs) and glycoproteins, growth factors, cytokines and chemokines. Our results were matching the conclusion found by Todros et al. (30) that tracheal rupture was successfully repaired lumen by suturing a free pericardial patch at the edges of tracheal rupture in combination with BioGlue on the outer patch surface and by covering tracheal repair with a pedicled serratus anterior muscle flap.

Emphysema wasn't developed post-operatively in both group which indicates the perfect sealing the defect by the biomaterial tissues. In both groups, adhesion was developed between grafting area and surrounding tissues as a result of inflammatory response to tissue injury and materials grafting (31).

The implantation of a foreign material into the body will face one of the three reactions: (i) lysis, (ii) inclusion and (iii) rejection (32). In group two, the excellent fusion of bovine pericardium membrane with trachea was showed due to ability of pericardium tissue for stretching and enfolding around the wound. Bovine pericardium. is considered as one of the most suitable choices for barrier material in guided tissue regeneration procedures (33). In group one, the repaired tracheal defects with autologous ear cartilage produced perfect results through the perfect inclusion of the implanted cartilage with the tracheal tissue and this was in agreement with the results of other studies $(34,35)$ that found the repair of larger defects is necessary to use cartilage implants and this has been investigated primarily for use in laryngotracheal reconstruction (LTR) after stenosis.

In both groups there were infiltration of monocular inflammatory cells (lymphocyte, macrophage and plasma cells). These features were resembled to Gilbert et al. (36) that such prosthetic materials may lead to allergic reaction and infection that cause to infiltration of mononuclear inflammatory cells. The infiltration was higher in tracheal grafting with pericardium due to the sever defense mechanism that produced from the tissue of animal therefore the pericardium was treated with some agents previous to operation or implantation to reduce the cellular antigenicity (decellularization) of it to reduce the host immune tissue response (37). Also, if acute inflammatory reaction is unable to eliminate the injurious agent or return injured tissue to its normal physiological state, the condition could change into a of chronic inflammation (38).

The occurrence of necrosis and degeneration of tracheal cartilage in some area of the site of cutting may be due to ischemia that result from interruption of blood supply and innervations during removal tracheal segment. The developmental of epithelium of tracheal mucosa was not shown and this is regarded the major problems in tracheal prosthesis $(39,40)$.

New cartilage formation was showed in both groups these findings reveled the ability to use ear cartilage and scaffold calve pericardium to repair the tracheal defect. the pericardium evokes to formed a new cartilage as this biomaterial grafts (bovine pericardium) act as a regenerative framework that supports remodeling and new collagen deposition.(41), also it contain a growth factors (27-29). The cartilage regeneration in group one was faster than that in group 2 and this is in agreement with other studies $(42,43)$ that grafting of newly engineered autologous cartilage containing less differentiated chondrocytes and demonstrating collagen type II, appeared to be capable of complete re-union with the original cartilage fragments, when accurately fixed to the host cartilage. In conclusion, this study approved the ability of using pericardium and ear cartilage grafts for repairing tracheal defect successfully particularly that of ear cartilage graft.

\section{References}

1. Getty R. The anatomy of the domestic animals. $5^{\text {th }}$ ed. New York: WB Saunders Company; 1975. 1567-1568 p.

2. Aspinall V, Capello M, Japery A. Text book of introduction to veterinary anatomy and physiology. $2^{\text {nd }}$ ed. London: Butter Worth Heinman; 2009. 90-96 p.

3. Evans HE. The respiratory system. $3^{\text {rd }}$ ed. Philadelphia: WB Saunders; 1993. 479-480 p.

4. Weissberg D, Utkin V. Airway trauma: tracheobronchial trauma. In: Webb WR, Besson A. Thoracic surgery: Surgical management of chest injuries. St. Louis: Mosby Year Book; 1991. 392-6 p.

5. Marty-Ané CH, Picard E, Jonquet O, Mary H. Membranous tracheal rupture after endotracheal intubation. Ann Thorac Surg. 1995;60(5):1367-71. DOI:10.1016/0003-4975(95)00643-Y

6. Shaff SI. Plastic adhesive for non- suture repair of tracheal wounds. JAVMA.1963;143:158-9.

https://www.ncbi.nlm.nih.gov/pubmed/14042909

7. Neville WE, Bolanowski PJ, Kotia GG. Clinical experience with the silicone tracheal prosthesis. J Thorac Cardio Vasc Surg. 1990;99(4):604-12. https://www.ncbi.nlm.nih.gov/pubmed/2319780

8. Cull DL, Lally KP, Mair EA, Daidone M, Parsons DS. Tracheal reconstruction with polytetrafluoroethylene graft in dogs. Ann Thorac Surg. 1990;50(5):899-901.DOI:10.1016/0003-4975(90)91116-s. 
9. Okumura N, Nakamura T, Natsume T, Tomihata K, Ikada Y, Shimizu Y. Experimental study on a new tracheal prosthesis made from collagen-conjugated mesh. J Thorac Cardio Vasc Surg.1994; 108(2):337-45. https://www.ncbi.nlm.nih.gov/pubmed/8041181

10. Schauwecker HH, Gerlach J, Planck H, Bucherl ES. Isoelastic polyurethane prosthesis for segmental tracheal replacement in beagle dogs. Artif Organs.1989;13(3):216-8.DOI:10.1111/j.15251594.tb02866.x

11. Jianxing HE, Xin X, Manyin ChenA, Shuben L, Weiqiang I, Yin S, Wang A, Yingying G. Novel method to repair tracheal defect by pectoralis major myocutaneous flap. Ann Thorac Surg. 2009;88(1):288-291.DOI10.1016/j.athoracsur.2008.11.030

12. Belsey R. Resection and reconstruction of the intrathoracic trachea. $\mathrm{Br}$ J Surg. 1950;38(150):200-5. https://doi.org/10.1002/bjs.18003815008

13. Grillo HC. Development of tracheal surgery :a historical review. Part 2:Treatment of tracheal diseases . Ann Thorac Surg. 2003;75:103947.DOI:10.1016/s0003-4975(02)04109-7

14. Macchiarini $P$, Jungebluth $P$, Go T, Asnaghi MA, Rees LE, Cogan TA. Clinical transplantation of a tissue-engineered airway. Lancet. 2008;372:2023-30.DOI :10.1016/S0140-6736(08)61598-6.

15. Walles T, Giere B, Hofmann M, Schanz J, Hofmann F, Mertsching H.,Macchiarini P.Experimental generation of a tissue-engineered functional and vascularized trachea. Thorac Cardiovasc Surg. 2004;128(6):900-6.DOI:10.1016/j.jtcvs.2004.07.036.

16. Macchiarini $P$, Walles $T$, Biancosino $C$, Mertsching H. First human transplantation of a bioengineered airway tissue. J Thorac Cardiovasc Surg. 2004;128(4):638-41.DOI:10.1016/j.jtevs.2004.02.042.

17. Ohara K, Nakamura K, Ohta E. Chest wall deformities and thoracic scoliosis after costal cartilage graft harvesting. Plast Reconstr Surg. 1997;99(4):1030-6.DOI:10.1097/00006534-199704000-00017.

18. Duncan MJ, Thomson H, Mancer JFK. Free cartilage grafts: The role of perichondrium. Plast Reconstr Surg. 1984;73(6):916.DOI:10.1097/00006534-198406000-00010.

19. Eisemann ML. The growth potential of autograft cartilage: An experimental study. Arch Otolaryngol. 1983;109(7):469-472.DOI: 10.1001/archotol.1983.00800210045011

20. Richard WQ. Experimental tracheal reconstruction with external ear canal autografts. Arch Otolaryngol. 1978;104(6):311-312.DOI: 10.1001/archotol.1978.00790060013003

21. Escande R, Nizar K, Isabelle DC, Caroline R, Maguette B, Fatima M, Frederic H, Didier L, Emmanuel L, Anne MP. Pericardial Processing: Challenges, Outcomes and Future Prospects, Biomaterials Science and Engineering. 2011. www.intechopen.com .DOI:10.5772/24949

22. Vidne B, Levy MJ. Use of pericardium for esophagoplasty in congenital esophageal stenosis surgery.1970;68(2):389-92. https://www.ncbi.nlm.nih.gov/pubmed/5450721

23. Gry H, Goss CM. Anatomy of human body. Philadelphia: Lea and Fibiger. 1973;542:1137.

24. Hasse J. Patch closure of tracheal defects with pericardium /PTFE :a new technique in extended pneumonectomy with carinal resection. Eur J Cardiothorac Surg. 1990;4(8):412-5.DOI:10.1016/10107940(90)90069-c

25. Moghissi K. Tracheal reconstruction with a prosthesis of marlx mesh and pericardium. J Thorac Cardiovas. Sur. 1975;69(4):499-506. https://www.ncbi.nlm.nih.gov/pubmed/1090786

26. Athar Y, Zainuddin SLA, Berahim Z, Hassan A, Sagheer A, Alam MK. Bovine pericardium: A highly versatile graft material. Inter Med J. 2014;21(3):321-324. https://web.b.ebscohost.com

27. Shukla A, Nandi P, Ranjan M. Acellular Dermis as a Dermal Matrix of Tissue Engineered Skin Substitute for Burns Treatment. Ann Pub Heal Res. 2015;2(3):1023. https://pdfs.semanticscholar.org
28. Swinehart IT, Badylak SF. Extracellular matrix bioscaffolds in tissue remodeling and morphogenesis. Develop Dynamics. 2016;245(3):351360.DOI:10.1002/dvdy.24379.

29. Verwoerd-Verhoef HL, Bean JK, Ten Koppel PG, Van Osch GJ, Verwoerd CD, Meeuwis JA. Induction in vivo of cartilage grafts for craniofacial reconstruction. Am J Rhinol. 1998;12(1):2731.DOI:10.2500/105065898782103061.

30. Todros S, Pavan PG, Natali AN. Biomechanical properties of synthetic surgical meshes for pelvic prolapse repair. J Mech Behave Biomed Mater. 2016;55:271-285.DOI:10.1016/j.jmbbm.2015.10.024.

31. Anderson JM. Biological Response to Materials. Annu Rev Mater Res. 2001;31:81-110.DOI:10.1146/annurev.matsci.31.1.81.

32. Yousaf A, Siti L, Akmar Z, Zurairah B, Akram H, Aamina S, Mohammad KA. Bovine Pericardium: A Highly Versatile Graft Material. Inter Med J. 2014;21(3):321-324. https://web.b.ebscohost.com

33. Christophoros NF, Marina S, Dimitrios $M$, Konstantinos $H$. Pericardial patch repair of an extensive longitudinal iatrogenic rupture of the intrathoracic membranous trachea. Elsevier B.V. Inter Cardiovasc Thorac Surg. 2003;2(4):595-597.DOI:10.1016/s15699293(03)00142-7.

34. Kojima K, Bonassar LJ, Roy AK, Vacanti CA, Cortiella J. Autologous tissue-engineered trachea with sheep nasal chondrocytes. J Thorac $\begin{array}{lll}\text { Cardiovasc } & \text { Surg. } & \text { 2002;123(6):1177- }\end{array}$ 1184.DOI:10.1067/mtc.2002.121116

35. Kojima K, Bonassar LJ, Roy AK, Mizuno H, Cortiella J, Vacanti CA. A composite tissue-engineered trachea using sheep nasal chondrocyte and epithelial cells. FASEB J. 2003;17:823-828.DOI:10.1096/fj.020462 com.

36. Usher IC, Fries JG, Ochsner JI, Tuttle LLD. Marlex mesh.a new plastic mesh for repairing tissue defects. Clin Stud AMA Arch Surg. 1995;78(1):138-45. DOI:10.1001/archsurg. 1959.04320010140023

37. Gilbert TW, Sellaro TL, Badylak SF. Decellularization of tissues and organs.Biomaterials.2006;27(19):3675-3683. DOI:10.1016/j.biomaterials.2006.02.014.

38. Greenberg JA, Clark RM. Advances in suture material for obstetric and gynecologic surgery. Rev Obstet Gynecol. 2009;2(3):146-158. https://www.ncbi.nlm.nih.gov/pmc/articles/PMC2760901/.

39. Delaere PR, Liu Z, Sciot R, Welvaart W. The role of immunosuppression in the long-term survival of tracheal allografts. Arch Otolaryngol Head Neck Surg. 1996;122(11):1201-1208. https://www.ncbi.nlm.nih.gov/pubmed/8906055

40. Jhingook K, Soo WS, Ji YS, Jin HK, Yong S, Hojoong K. Replacement of a tracheal defect with a tissue-engineered prosthesis: Early results from animal experiments. J Thorac Cardiovasc Surg. 2004;128(1):124-129.DOI:10.1016/j.jtcvs.2003.09.045

41. Pascual G, Sotomayor S, Rodriguez M, Perez-Kohler B, Bellon JM. Repair of abdominal wall defects with biodegradable laminar prostheses: polymeric or biological. PLOS. 2012;7(12):e52628.DOI: 10.1371/journal.pone. 0052628

42. Bean JK, Verwoerd-Verhoef HL, Meeuwis J, Verwoerd CD. Reconstruction of the growing cricoid with a composite graft of demineralized bovine bone and auto-genous perichondrium. Int J Ped Otorhinolaryngol.1993;25:163-172. https://www.ncbi.nlm.nih.gov/pubmed/8436461

43. Silver FH, Glasgold AI. Cartilage wound healing; an overview. Otolaryngol Clin North Am.1995;28(5):847-864. https://www.ncbi.nlm.nih.gov/pubmed/8559576 